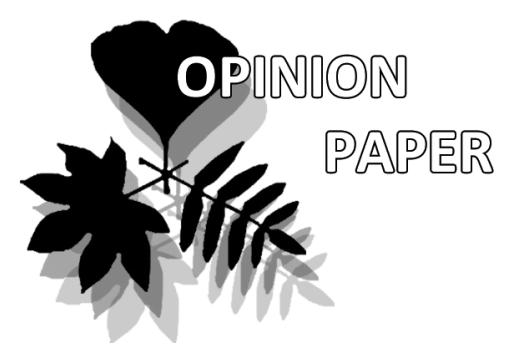

In one of his last works Valentin Krassilov wrote: "My professional field was biostratigraphy". But it is not. The philosophy and evolution are the quintessence of his scientific heritage.

\title{
The Bouquet of Evolutionary Coherences: The Prospects of the System Theory of Evolution
}

\author{
Alexander A. Protasov
}

\section{Alexander A. Protasov}

e-mail:pr1717@ukr.net

Institute of Hydrobiology of National Academy of Sciences of Ukraine, Kiev, Ukraine

Manuscript received: 21.06.2015 Review completed: 20.10 .2015

Accepted for publication: 20.10.2015

Published online: 21.10.2015

\begin{abstract}
A B S T R A C T
The majority of modern evolution theories are based on principles of reductionism, they consider potential or actual processes of biological evolution. They do not take into consideration that the biosphere evolves as a whole system. The system theory of evolution elaborated by V.A. Krassilov uses the concept of succession, which links main aspects of ecosystems' structure and functioning. A core element of the theory is the concept of coherence/non-coherence in evolution. However, the coherence concept, both in ecosystem evolution and in biological evolution in general, seems to be of much higher importance, compared to what was initially stated by its author.
\end{abstract}

K e y w o r d s : evolution, the system theory, coherence, ecosystem, biosphere

\section{P E 3 Ю M E}

Протасов А.А. Букет эволюционных когерентностей: перспективы системной теории эволюции. Большинство современных эволюционных теорий основаны на принципах редукционизма, они рассматривают возможные или реальные процессы биологической эволюции. Они не принимают во внимание, что биосфера эволюционирова^а как единая система. Системная теория эволюции, предложенная В.А. Красиловым, использует понятия сукцессии, связана с основными представлениями о структуре и функционировании экосистем. Важное место в теории занимает концепция опредеменных периодов когерентной и некогерентной эволюции. ПреАставАяется, что концепция когерентности как в экосистемах, так и в эволюционном процессе, имеет гораздо более широкое значение, чем было показано автором системной теории эволюции.

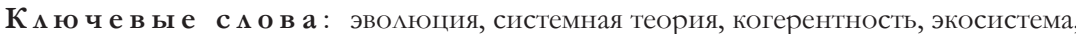
биосфера
Nowadays, reductionism triumphally predominates in evolutionary theories. The reductionism/holism disbalance forces to rethink of the ways of evolutionary theories' development. The dominance of one of the viewpoints reduces diversity in the field of scientific search, which corresponds to increase in entropy. Theories of Darwinian type put competitive inter-organismic relationships and therefore selection as a core evolutionary process, thus overlooking or even totally ignoring interactions within the biosphere and its structure (Vernadsky 1926).

With this respect, the system theory of evolution (Krassilov 1992, 2014) is more broad-based; while the Darwinian "origin of species" reflects only one evolutionary trend in the biosphere's development as a whole system. Valentin Krassilov entitles his concept as the system theory of evolution; however, a narrower name, "ecosystem theory", is also used (Lashin et al. 2012). It seems reasonable given that the biosphere is the system of ecosystems at all stages of their development and is necessarily structured (Protasov 2013).

A key statement within this theory is the analogy between ecological succession process and evolutionary deve- lopment. Another important issue - entropy dynamics, developmental direction, teleology, follow from this succession concept. However, posing the parallels between similar systems requires considering these systems' features; parallels do not imply total identities.

It is necessary to notice that the concept of ecological succession has been already developed for a century (Clements \& Shelford 1939). Ecological processes can be directly observed and estimated, in contrast to evolutionary ones. The ecological succession or ecosystems' development is defined in several parameters (Odum 1969). The succession is the ordered process resulting in structural changes; this process is definitely directed, and thus is predictable. It is worth noting that while considering open systems' development, Krassilov (1992, 2014) came to a wider generalization: for such systems some purpose of development is believed to exist. Such a purpose is increase in orderliness or decrease in entropy.

Ecological processes are accompanied by changes in the physical environment caused by biotic communities. Though the environment defines the character of a succession, the 
latter is constantly affected by the community. Therefore, it is necessary to consider "general design" of communities and degree of the impact.

Communities can be located in biocoenotic gradient (Protasov 2011). On the one end of this gradient, there are communities with well-expressed dominant, capable to modify the conditions. On the other end, there are communities without explicit dominant that are defined statistically. In this case, the interactions are weak, and the community is governed primarily by the environment. The communities of coral reefs or rainforests may be viewed as examples for the first case; while the communities of deserts and oceanic bottoms - the second one. It is important to emphasize that communities of both types (as well as intermediates) can be terminal, climax under the given conditions and structure.

The statements posed by Zherikhin (1986) are close to the above mentioned ones. Following organismic and species-individualistic approaches of Clements, Ramensky and Gleason (Clements \& Shelford 1939, Stohlgren 2007), he emphasized that the communities are polarized. However, like the founders of the both approaches, he saw only poles themselves, not the gradient between them. At the same time, such gradient structure is omnipresent. The widespread concept of $K / r$ gradient explicitly corresponds to community structure (Pianka 1970). As a rule, $K$-strategists become dominant and key-stone elements in communities with consortium-like structure, whereas $r$-strategists form communities with weak coenotic interactions. In other words, the major question is which strategy species prefer: high productivity with high mortality in low species richness communities or high surviving in high species-rich communities but with low productivity (so called, Niobe or Latona strategies) (Krassilov 2014).

With this respect, it is impossible to assume that in evolutionary time ecosystems develop only towards the first type communities, with "climax" components prevailing (Krassilov 1992). But what the structure of communities and the net production decreases during community succession, means that expenses of energy for maintenance of more and more difficult structure increases. The increase in complexity of ecosystems and the biosphere in general is a major evolutionary trend. However, the external energy deficiency may limit system complication.

The paleontological annals represent some fossils that are basis for estimation of some biota characteristics, such as taxonomic and ecomorph diversity. The estimates of community diversity, their diversity and evenness are less reliably.

Proceeding from reasonable ecological logic, increase in taxa quantity should be considered as an indicator for increase in environmental capacity and for decrease in biotic competition (or increase in symbiotic interactions). Therefore, hyperbolic curve, depicting the growth of integrated taxonomic richness (Markov \& Korotayev 2008), is consistent with the growth of organizational complexity of the biosphere, as well as with complexity of intra- and extraecosystem interactions. Whereas diversity that corresponds to entropy is decreased, reduction of evenness growth is not obvious. The species-edificators prefer the first-type communities (see above) if complexity of communities in- creases as a result of many relationships in the center of consortia-type communities with formally low evenness (or high domination). However generally, main trend of steady growth of taxon richness and the general complexity in biosphere evolution occurred at periodic increase and decrease taxonomic richness during biota change. Of course evolutionary processes had character when more or less stable periods alternated with crises (Krassilov 1992).

Such as alternation generates the question: is the general trend just a part of the trend of a higher-level trend, as it was in the beginning of evolution of Cambrian, Paleozoic, Mesozoic-Cenozoic biotas? Thus, the concept of coherent/non-coherent evolution (Krassilov 2014) can be further rethought. Coherence (from Latin cobaerentia - being in communication) is the connectivity of processes. This implies that the difference in fluctuation phases remains constant in time. Obviously, that long existence of ecosystems is impossible without coherence (both in time and space) in primary production, consumption of organic matters, returning of biogenic substances to producers. It is possible to add Odum's model of succession with increase of coherent processes. Coherence increase is a result of an increasing of organization of an ecosystem. The climax condition can be considered as the condition with maximal and optimal coherency. Under certain conditions, communities and ecosystems may stay at such a state for an indefinitely long time. It is possible to assume that with increase in organization of bioinert systems, their stability increases. The more organized systems are the more powerful external impact they may endure. An ecosystem can be destroyed or strongly damaged by a local hurricane, flooding, etc. Cardinal changes in a biogeome, which is a set of the similar ecosystems (there can be whole geological epoch), are connected with global changes of planetary scale. The biosphere exists for about 4 billion years, as much as the Earth life does. We should strongly emphasize that stability and quasistability of higher-level systems is maintained by dynamical changes in their internal elements. The evolution of species within ecosystems, and the evolution of ecosystems within biogeomes (which are elements of the biosphere) becomes the inevitable phenomenon, a precondition for existence of bioinert systems! The biosphere evolution, as a global process, is top-down regulated (Krassilov 1992, 2014).

The end of a coherent phase, and transition to crisis conditions is defined not only by external impacts, up to the space periodic phenomena as it is proved by the author of the system theory, but should have and the internal reasons for system, coherent evolution, probably with the dual nature. On the one hand, it runs towards maintenance of stability of a system as a whole, on the other - it accumulates certain internal contradictions. That is non-coherency, preconditions of the crisis phenomena become ripe already in climax coherent systems. That was by Krassilov defined as crisis, which most likely, is a change of revolutionary type.

Other interesting concepts to address are system fatigue and crisis processes. Thus, during the ontogenesis, although reparation and regulation take place, the organism accumulates deleterious changes causing ageing and death. As likely 
as not, the organism may succeed in prolonging its existence, although this may require the increasing expenses of energy. Yet, is this what the population does need? Does the biosphere need semper-climax ${ }^{1}$ communities and "immortal" ecosystems? The negative answer to this question has two important consequences. First, the biosphere is top-down regulated only. Second, any system cannot evolve and improve infinitely, with furthermore energy being spent to maintain more complicated, although invariant, structure.

With this respect, Krassilov's (1986) point of view on human evolution is rather interesting. He asks whether the human uniqueness owes to its ability to change without changes. And infers a very important evolutionary shift: in humans, evolution has mostly moved to the cultural sphere.

This work is worth citing, since it addresses extremely important principals of evolutionary sort: "In the history of a life on the Earth the evolution course twice abruptly changed: the first time on transition from the elementary to unicellular organisms when possibilities of biochemical per fection basically have been settled, progress was displaced towards morphology, and the second - in connection with occurrence of the human culture which have accepted relay race of progress from morphology. Each of these turns designates the beginning of qualitatively new stage of evolution, irreducible to previous" (Krassilov 1986: 80, 2014).

Krassilov (1986: 81) noted that "human is evolutionary unique, because his evolution nearly completely shifted into the environment of culture". This shift was a unique evolutionary event, which enabled new evolution trend (Protasov 2015).

With regard to the complexity and diversity of crisis phenomena, despite the importance of external factors, they are based on systems' internal processes. One of the mechanisms appeals to interactions between the environment's and the bioinert systems' diversity (Zherikhin 1986). It is based on one of the diversiology lows, formulated by Ashby (1957: 207): "Variety can destroy variety", however the nature always demonstrates that variety also maintains variety. To cope with the variety of environmental adverse impacts, community should oppose the variety of destabilization resistance mechanisms. Besides, the more diverse environmental impact becomes, the more energy is required for the community to maintain its own complexity and diversity. Thus, it appears that "all methods of regulating the evolution are probabilistic and not totally reliable" (Zherikhin 1986: 12). From this one may infer that, even in absence of any destructive environmental factors, "community will be destroyed some time or other due to the evolution of its elements, despite the mechanisms suppressing this evolution" (Zherikhin 1986: 12).

${ }^{1}$ This term (from Latin semper - always, and Ancient Greek $x \lambda \hat{u} u a \xi$ - culmination) is introdused here for defining the hypothetical terminal steady state in the processes of succession in ecosystem in evolution. At the scale of human life-span, we are able to see quite long-living communities. However, nothing lasts forever, and once upon a time some trigger starts the process of destroying the structure of community at the certain state of the climax, and the community acquires some pioneer features. Therefore, it cannot be always in climax state that would mean the immortality of community, as there are always factors changing its structure from a stable climax stage. Valentin Krassilov approached this problem in his publications during his all life (Krassilov 1977, 2014).
The deaths of communities and ecosystems are also necessary for the biosphere to evolve, as well as their lives.

In evolution, not only directional, but also fluctuating processes take place. However, this periodicity goes as though counter with the general idea of evolution that is more «forward and irreversible» than pulsing. Lyubishchev (1982: 141) considered this contradiction to be one of the manifestations of crisis in modern evolutionary sort ("crisis of concept of evolution"). The famous Linnaeus's "nature does not make a jump" is still a postulate. Indeed, within Darwinian framework, evolution proceeds via gradual accumulation of small changes.

Opposing the concepts of evolution and revolution generates some important questions. Whether these processes are mutually exclusive, or complementary, therefore being parts of a higher-level process? What are its components and whether it is possible to talk about functional megaevolutionary necessity for constructive "creative" processes of evolution and destructive revolutions?

Many features of ecological succession and evolution essentially differ. The ecosystem organizational level is quite finite and balanced in terms of potential energy costs needed for its maintenance. At the evolution level, perhaps, it is necessary to talk about existence of "pressure of evolution", formations of such organizational level when development is already impossible under existing ways of energy usage and way of its transformation. An external pushing factor (e.g., changes in the Earth's rotation parameters) quickly, in a revolutionary way, destroys the system, and is believed as the basic determinant.

As we may see, using the coherence concept is rather productive for both ecology and evolution theories. Further development of the system theory of evolution may require assuming the whole «bouquet» of coherencies.

The periods of counterbalanced, slow development are defined by Krassilov as coherent evolution (known also as Krassilov's coherence, or K-coherence, Protasov 2015). It is featured by coped, connected process (something like a laminar stream where all the particles move in one direction). Under crises, the periods of non-coherent evolution happen with one species dying while others rapidly occur (like "turbulization" process).

However, such processes (here again we do agree with the author of the concept) occur not "to the nature in general", but to certain ecosystems or biogeomes. Not only biota (taxa) changes but ecosystems as well. But there is one more important point that by Berg (1926) defined as "epidemic" character of speciation, mass formation of new (often similar) species on enormous territory. Thus, under non-coherent, "turbulization" evolution, another kind of coherence may exist, when the: "turbulizations" cover the biosphere quite harmoniously (chorological-time coherence, or C-coherence).

Since there were no important abiotic reasons, such as changes in the ocean's thermal regime (Fedonkin 2003) this process might be caused biologically, and with help of diverse evolutionary trends as biochemical and ecomorph.

Another important type of coherence is the coordination of evolutionary changes in different trends (trends-cohe- 
rence, or T-coherence). For example, "ornitization" resulted from changes in both biochemical (feathers, histologic updating's of a skeleton, muscle) and physiological (changes of blood circulation, breath) trends. The type of moving system - arthropterial - was also essentially modified as a component of the ecomorph trend. The approach with taxonomic trends should become more active essentially as the new "models" that can be approved on many species of reptiles. The theories of the biological evolution, which originate from Darwinism, explain only one (although important) part of the whole process. But only the system approach seems to be a success, since it considers the evolution of the biosphere as a whole.

\section{LITERAT URE CITED}

Ashby, W.R. 1957. An introduction to cybernatics. Second edition. Chapmann and Hall LTD, London.

Berg, L.S. 1926. Nomogenesis: or, evolution determined by law. M.I.T. Press, Cambridge, 477 pp.

Clements, F.T. \& V.E. Shelford 1939. Bio-Ecology. Wiley \& Sons, Inc., N.Y., VI+425 pp.

Fedonkin, M.A. 2003. The origin of the Metazoa in the light of the Proterozoic fossil record. Paleonthological Research 7(1):9-41.

Krassilov, V.A. 1977. Evolution and Biostratigraphy. Nauka, Moscow, 256 pp. (in Russian). [Красилов В.А. 1977. Эвомюция и биостратиграфия. Москва: Наука. 256 с.].

Krassilov, V.A. 1986. Unsolved Problems of Evolutionary Theory. Dal'nauka, Vladivostok, 147 pp. (in Russian). [Красимов В.А. 1986. Нерешенные проблемы эволюционной теории. ВАаАивосток: Аальнаука. 147 с.].

Krassilov, V.A. 1992. Nature Conservation: Principles, Problems, Priorities. Institut okhrany prirody, Moskva, 173 pp. (in Russian). [Красилов В.А. 1992. Охрана природы: Принципы, проблемы, приоритеты. М.: Институт охраны природы. 172 с.].

Krassilov, V.A. 2014. Evolution: System Theory. Pensoft, Sofia, Moscow, 414 pp.

Lashin, S.A., J.G., Suslov \& J.G. Matushkin 2012. Theories of biological evolution from positions of modern development of system biology. Genetika 48(5):573-569 (in Rus- sian). [Аашин С.А., Суслов Ю.Г., Матушкин Ю.Г. 2012. Теории биологической эволюции с позиций современного развития системной биологии // Генетика. T. 48, № 5. C. 573-569].

Lyubishchev, A.A. 1982. Problems of the form, systematics and evolution of organisms. Nauka, Moskva, 376 pp. (in Russian). [Аюбищев А.А. 1982. Проблемы формы, систематики и эволюции организмов. Сборник статей. Москва: Наука. 376 с.].

Markov, A.V. \& A.V. Korotaev 2008. Hyperbolic growth of marine and continental Phanerozoic biota and evolution of communities. Zhurnal Obshchei Biologii 69(3):175-194 (in Russian). [Марков А.В., Коротаев А.В. 2008. Гиперболический рост разнообразия морской и континентальной биот фанерозоя и эволюция сообществ // Журн. общ. биол. Т. 69, № 3. С. 175-194].

Odum, E. 1969. The strategy of ecosystem development. Science 164:262-270.

Pianka, E.R. 1970. On $r$ and $K$ selection. American Naturalist 104(940):592-597. doi:10.1086/282697

Protasov, A.A. 2011. Life in Hydrosphere. Sketches on the general bydrobiology. Akademperiodika, Kiev, 704 pp. (in Russian). [Протасов А.А. 2011. Жизнь в гидросфере. Очерки по общей гидробиологии. Киев: Академпериодика. 704 c.].

Protasov, A.A. 2013. Macrostructure of Biosphere and a place of biogeome in it. Biosfera 5(4):384-392 (in Russian). [Протасов А.А. 2013. Макроструктура биосферы и место в ней биогеома // Биосфера. Т. 5, № 4. С. 384-392].

Protasov, A.A. 2015. Trends in the evolutionary system in the biosphere. Biosfera 7(3):289-294 (in Russian). [Протасов А.А. 2015. Тренды в эволюционной системе биосферы // Биосфера. Т. 7, № 3. С. 289-294].

Stohlgren, T.J. 2007. Measuring Plant Diversity: Lessons from the Field. Oxford University Press, Oxford, New York, 390 pp.

Vernadsky, V.I. 1926. Biosphera. Nauchnoe khimiko-tekhnicheskoe izdatel'stvo, Leningrad, 146 pp. (in Russian) [Bepнадский В.И. 1926. Биосфера. А.: Научное химикотехническое издательство. 146 с.].

Zherikhin, V.V. 1986. Biocenotic regulation of evolution. Paleontologicheskii Zhurnal 1: 3-12 [Жерихин B.B. 1986. Биоценотическая регуляция эволюции // Палеонтомогический журнац. № 1. С. 3-12]. 